\title{
NORMAS TRIBUTÁRIAS COMO INSTRUMENTO DE INFRAÇÃO À ORDEM ECONÔMICA (INTERNA E INTERNACIONAL)
}

\author{
TAX RULES AS AN INSTRUMENT OF INFRINGEMENT TO THE \\ ECONOMIC ORDER (DOMESTICAND INTERNATIONAL)
}

\author{
Victor Monteiro Almeida ${ }^{1}$
}

\section{RESUMO}

Cotidianamente as doutrinas especializadas ofertam estudos de suas respectivas searas isoladamente, sem perquirir as repercussões que cada fenômeno sucedido em determinada ramo do direito ocasiona reflexamente nas demais égides. A digressão científica proposta partirá da premissa de que o sistema do direito positivo é uno e indecomponível, para então se debruçar sobre as consequências que as anomalias protagonizadas pelas normas prescritivas de regras tributárias surtem sobre a ordem econômica. Fixar-se-ão pressupostos elementares para, a partir deles, desenvolver toda a linha de raciocínio que conduzirá à conclusão. $\mathrm{Na}$ conclusão, socorrer-se-á de exemplos práticos buscando identificar as consequências práticas do estudo teórico abordado, indicando de que forma as normas tributárias podem instrumentalizar infrações à ordem econômica (interna e internacional).

Palavras-Chave:Sistema de Direito Positivo; Sistema Uno e Indivisível; Normas Tributárias; Infração à Ordem Econômica Interna e Internacional.

ABSTRACT: Routinely, specialized doctrines produce studies of their respective fields alone, without realizing the repercussions that each phenomenon pertaining to certain branches of the law cause on other fields. The proposed scientific digression will start with the premise that the system of positive law is one and indecomposable, and then address the consequences of anomalies carried out by the tax rules prescriptive norms on economic order. Elementary assumptions will be established to develop the whole line of reasoning that will lead to the conclusion. Concluding, practical examples will be used to identify the practical consequences of the theoretical study, indicating how tax rules can instrument infractions to the economic order (domestic and international).

Keywords: Positive Law System; One and Indecomposable System; Infringement to Domestic and International Economic Order.

\footnotetext{
${ }^{1}$ Advogado regularmente inscrito na OAB/AL. Pós-Graduado em Direito Processual Civil pela Universidade Anhanguera - Uniderp. Pós-Graduando em Direito Tributário pelo Instituto Brasileiro de Estudos Tributários - IBET. Mestrando em Direito Tributário pela Pontifícia Universidade Católica de São Paulo - PUC-SP. Membro Titular da Comissão de Estudos Tributários da Ordem dos Advogados do Brasil Seccional Alagoas - CET OAB/AL.
} 


\section{SUMÁRIO}

Introdução. 1. Ordem Jurídico-Econômica no Brasil. 1.1. Objeto do Direito Econômico. 1.2. Políticas de Intervenção na Ordem Econômica. 1.3. Instrumentos de Intervenção na Ordem Econômica. 2. A Intervenção do Estado no Domínio Econômico: Infrações à Ordem Econômica. 2.1.Infrações à Ordem Econômica: Infrações Próprias. 2.2. Normas Tributárias Como Instrumentos de Intervenção. 2.2.1. Normas Tributárias Como Instrumentos de Intervenção: Espécies Tributárias. 2.3. Infrações à Ordem Econômica: Infrações Impróprias (Instrumentalizadas Por Meio de Normas Tributárias). 3. Infrações à Ordem Econômica Internacional. 1.Conceito de Ordem Econômica Internacional. 3.2. Infrações à Ordem Econômica Internacional Instrumentalizadas Por Meio de Normas Tributárias. Considerações Finais. Referências.

\section{INTRODUÇÃO}

O direito é um sistema de linguagem que opera com normas prescritivas, as quais tem por objeto a regulamentação das condutas intersubjetivas, distinguindo-se dos demais sistemas reguladores de condutas (ética, religião, etc.) em razão de seu peculiar caráter coercitivo.

Peculiaridade outra própria ao direito, é a ramificação de suas normas em escalões hierárquicos, as quais sempre buscam seus respectivos fundamentos de validade nas normas hierarquicamente superiores; para KELSEN (1999, p. 217/221), o fundamento de validade de todas as normas seria a norma hipotética fundamental.

Fixadas estas premissas, de pronto evidenciamos que o sistema de direito positivo é uno e indivisível, já que todas as normas prescritivas deste sistema derivam da norma hipotética fundamental; ou ainda, da Constituição da República Federativa do Brasil de 1988.

Entretanto, exatamente em razão do potencial de surgimento de infinitas normas hierarquicamente escalonadas, seria humanamente impossível estudar o direito positivo como um todo, motivo pelo qual a ciência do direito promove a segregação deste sistema em ramos.

Esclarecemos, de $\log$ o, que a ciência do direito é um sistema que opera com a linguagem descritiva e que tem a linguagem prescritiva do direito positivo como objeto de estudo. Assim, a segregação protagonizada pela ciência do direito é legítima, ao passo que esta não detém a pretensão de modificar o mundo, possuindo finalidade meramente didática. 
E são exatamente estas ramificações, instrumentalizadas por meio de cortes metodológicos, que nos autoriza a proclamar a autonomia do direito econômico, do direito tributário, do direito trabalhista e, até mesmo, do direito constitucional; e de outras infinidades de égides do direito (direito penal, previdenciário, civil, administrativo, etc.). Todos estes ramos, frutos da doutrina enquanto ciência do direito.

Firmes nestes pressupostos, o estudo ora proposto tem a audaciosa ambição de abandonar os cortes metodológicos tradicionalmente sugeridos para investigar os reflexos que as normas editadas sob determinado ramo do direito têm sobre outros ramos.

Mais especificamente, pretendemos analisar as repercussões que as normas que prescrevem regras tributárias surtem no âmbito da ordem econômica (objeto do subsistema do direito econômico).

\section{ORDEM JURÍDICO-ECONÔMICA NO BRASIL}

\subsection{OBJETO DO DIREITO ECONÔMICO}

Pregresso à análise do objeto do direito econômico, necessário registrarmos o que compreendemos por direito. Valendo-nos das lições da Profa. Aurora Tomazine de Carvalho, sustentamos que o direito é o conjunto de normas válidas em determinado sistema prescritivo que serve como “instrumento, constituído pelo homem com a finalidade de regular condutas intersubjetivas, canalizando-as em direção a certos valores que a sociedade deseja ver realizados" (CARVALHO, 2013, p. 86).

Partindo desta premissa, coadunamos com os ensinamentos do Livre Docente Paulo de Barros Carvalho, o qual advoga que o sistema de direito positivo é uno e indivisível, somente comportando divisão para fins didáticos. Ou seja, o sistema do direito é um conjunto insegregável de normas; porém, a ciência do direito o segrega apenas para facilitar sua compreensão.

É nesse sentido que entrevemos a desvinculação do direito tributário com relação às demais construções do direito positivo, circunstância que lhe empresta, decididamente, traço particular e foros de autonomia, não científica, como de cotio se afirma, mas autonomia meramente didática, uma vez que o direito constitui sistema unitário e indecomponível, debaixo de 
qualquer pretexto, que não aquele que busca meios e formas de expor a arquitetura de seus institutos, segundo métodos adequados de compreensão.(CARVALHO, 2012, p. 379)

Com ainda maior assertividade, acrescenta o Doutor pela Pontifícia Universidade Católica de São Paulo, Prof. Nelson Nazar:

O direito, enquanto ciência descritiva, segundo a teoria de Hans Kelsen, representa um todo uno, um todo indivisível. Enquanto ciência, não pode ser fracionado. Segundo as lições do professor Geraldo Ataliba (1985, p. 3) (que recebeu muitas influências do pensamento kelseniano), quanto à questão da unicidade do direito, tem-se que o mesmo é um corpo uno e indivisível, um organismo perfeito, em que o conjunto normativo das regras vai estruturar um sistema de comandos. É lícito afirmar-se que o direito contém as suas próprias realidades.

(...)

Tanto no sentido descritivo como no prescritivo, o direito se enquadra em uma estrutura de comandos, que em tese não pode ser fracionada.

Mas o professor Geraldo Ataliba (1985) ensinava que não é possível se conhecer a ciência do direito como um todo, sem se dividir didaticamente os ramos do direito.

Pelo contrário, dá o modo de conhecer e aplicar o direito, de acordo com os compartimentos que são voltados para a qualidade da norma jurídica de cada setor do direito positivo.

$O$ fato de haver ramos do direito, estruturados em setores do conhecimento para serem estudados de forma distinta (são as Cadeiras que têm autonomia), não retira o caráter científico do direito.(NAZAR, 2014, p. 45)

Desta forma, concluímos que o direito é uma ciência interdisciplinar que não comporta ramificações em égides (direito econômico, financeiro, tributário, trabalhista, etc.); no entanto, esta segregação é valiosa para fins estritamente didáticos.

Assentada esta preambular inserção, agora abordaremos o objeto do direito econômico; socorrendo-nos, desta vez, às palavras do jus-filósofo Lourival Vilanova (2010, p. 265), o qual proclama que "o Direito positivo tem a pretensão de modificar o mundo; a ciência jurídica tem a pretensão de conhecer os módulos normativos de modificar o mundo".

Abraçando-nos às reflexões do mestre pernambucano, podemos conceber que a ciência do direito econômico é a ciência humana revestida de metalinguagem que tem por objeto o estudo do código linguístico competente para modificar a realidade da ordem econômica de determinado estado soberano; este (código linguístico), o direito econômico. Porém, surge aí nova problemática, o que compreender por ordem econômica? 
Por esta razão, trilharemos a digressão adiante traçando algumas conceituações sobre a concepção de ordem econômica.

Nas palavras do Prof. Leonardo Vizeu Figueiredo:

Por Ordem Econômica entende-se o tratamento jurídico disciplinado pela Constituição para a condução econômica da Nação, limitado e delineado pelas formas estabelecidas na própria Lei Maior para legitimar a intervenção do Estado no domínio privado econômico. (FIGUEIREDO, 2016, p. 42)

Já para o jurista Nelson Nazar (2014, p. 65), a expressão ordem econômica comporta mais de uma significação, registrando a seguinte ressalva:

A expressão "ordem económica" tem três sentidos:

- modo de ser empírico de uma determinada economia concreta;

- conjunto de todas as normas (morais, jurídicas e religiosas) sobre o comportamento dos sujeitos econômicos; e

- conjunto das normas jurídicas da economia.

De igual modo, o Prof. Vital Moreira também enxerga três possíveis significações para o termo ora examinado:

- em um primeiro sentido, "ordem econômica" é o modo de ser empírico de uma determinada economia concreta; a expressão, aqui, é termo de um conceito de fato e não de um conceito normativo ou de valor (é conceito do mundo do ser, portanto); o que o caracteriza é a circunstância de referir-se não a um conjunto de regras ou normas reguladoras de relações sociais, mas sim entre uma relação entre fenômenos econômicos e materiais, ou seja, relação entre fatores econômicos concretos; conceitos do mundo do ser, exprime a realidade de uma inerente articulação do econômico como fato;

- em segundo sentido, "ordem econômica" é expressão que designa o conjunto de todas as normas (ou regras de conduta), a qualquer que seja sua natureza (jurídica, religiosa, moral, etc.), que respeitam à regulação do comportamento dos sujeitos econômicos; é o sistema normativo (no sentido sociológico) da ação econômica;

- em um terceiro sentido, "ordem econômica" significa ordem jurídica da economia. (MOREIRA apud GRAU, 2018, p. 63).

Por sua vez, o Ministro Eros Grau (STF)igualmente defende que este termo (ordem econômica) é ambíguo, no entanto, compreende-o como parcela da ordem jurídica, atribui-lhe as seguintes significações:

19. Não obstante a obviedade das distinções apontadas - repito - a generalidade das pessoas se enreda na ambiguidade da expressão. E isso, tanto quando o leitor não pratica nenhum exercício de reflexão, soçobrando então na inconsequência a que o reduz sua incapacidade de raciocinar, quanto quando, 
embora o faça, não seja capaz de romper o mistério da ordem econômica. É esse mistério, de resto, responsável pelo fascínio que a expressão - tão-só a expressão - exerce sobre tantos.

É que a expressão "ordem econômica", ao ser utilizada como termo de conceito de fato, para conotar o modo de ser empírico de determinada economia concreta, apresenta essa mesma economia, realidade do mundo do ser, como suficientemente normatizada. Como o vocábulo "ordem", no seu amplo arco de denotações, significa, também, um conjunto ou mesmo um sistema de normas, a realidade do mundo do ser, quando referida pela expressão, é antecipadamente descrita (na síntese que a expressão encerra) como adequadamente "ordenada", isto é, normatizada e, portanto, regulada.

(...)Assim, ordem econômica, parcela da ordem jurídica (mundo do dever-ser), não é senão o conjunto de normas que institucionaliza uma determinada ordem econômica (mundo do ser). (GRAU, 2018, p. 65/68).

Com arrimo nas lições doutrinárias acima, para fins do presente estudo científico, adotaremos como significação de ordem econômica a que a concebe como um conjunto de normas legalmente positivadas no sistema jurídico de determinado País e que se volta a regulamentar as relações econômicas e sociais no âmbito interno deste Estado soberano.

Tomando como premissa este conceito de ordem econômica, ratificamos que direito econômico, enquanto doutrina, é a ciência humana que tem por objeto o estudo das normas que prescrevem regulamentações acerca da ordem econômica. Ou seja, direito econômico é a ciência revestida de metalinguagem que foca seu objeto de estudo na linguagem prescritiva das normas que regulamentam a ordem econômica.

Assim, pudemos delimitar o âmbito de atuação e o objeto de estudos do direito econômico; entretanto, ainda nos resta percorrer quais as formas de manipulação da ordem econômica e, por via de consequência, de crucial interesse ao estudo do direito econômico.

\subsection{POLÍTICAS DE INTERVENÇÃO NA ORDEM ECONÔMICA}

Neste subitem, debruçar-nos-emos sobre as políticas de intervenção do Estado no domínio econômico, as quais podem ser sintetizadas basicamente em duas espécies: o liberalismo e o intervencionismo.

Com a devida vênia à complexidade clamada pelo tema, o estudo científico ora proposto não nos permite maiores divagações, razão pela qual nos resguardaremos à breves e sintetizados comentários. 
A ideologia político-econômica do liberalismo apregoa que o Estado não deverá intervir em seu domínio econômico, resguardando-se ao papel de garantidor da ordem interna e defensor de sua soberania territorial; ao passo em que a ordem econômica se auto regulamentará. (VILELA, 2016, p. 37).

Já quanto à ideologia político-econômica do intervencionismo, tomando como premissa os ensinamentos do Prof. Vilela (2016, p. 38/39), poderemos subdividi-la em três subespécies: intervencionismo econômico, intervencionismo social e intervencionismo socialista.

A primeira subespécie (intervencionismo econômico) está umbilicalmente ligada aos direitos fundamentais de primeira dimensão, ao passo em que não se presta à intervenção no domínio econômico; mas sim, tão somente, a podar algumas liberdades individuais com o fim exclusivo de coibir seu exercício abusivo. Ou seja, pretende limitar algumas liberdades para coibindo o abuso - garantir o exercício da liberdade econômica pela coletividade.

Por sua vez, a segunda subespécie (intervencionismo social) correlaciona-se com os direitos fundamentais de segundo e de terceira dimensões, posto que supera o interesse de cunho eminentemente individualista e passa a focalizar nos interesses da coletividade. Nesta política intervencionista, o Estado atua de forma proativa (prestações positivas) na regulamentação do domínio econômico com vistas a garantir o bem-estar social (mínimo existencial).

Por fim, a terceira subespécie (intervencionismo socialista) afeiçoa-se como a "forma intervencionista máxima do Estado" (VILELA, 2016, p. 39), a qual se caracteriza pela centralização do controle do domínio econômico no seio do Estado por meio do monopólio das propriedades e meios de produção. O papel estatal, através de seu planejamento econômico, será o de distribuir bens e riquezas em detrimento, obviamente, das suprimidas liberdades econômicas (livre iniciativa e liberdade de mercado).

\subsection{INSTRUMENTOS DE INTERVENÇÃO NA ORDEM ECONÔMICA}

Já analisamos quais as políticas que determinado Estado soberano poderá adotar para intervir em sua ordem econômica - ou seja, qual a postura do Estado perante a ordem econômica -, restando-nos agora analisar quais as 
formas de instrumentalizar tais políticas (político-econômica intervencionista, já que a político-econômica liberalista não admite intervenção estatal).

O Min. Eros Grau propõe interessante classificação, segregando as modalidades de intervenção peculiares à ideologia político-econômica intervencionista.

54. Afirmada a adequação de uso do vocábulo intervenção, para referir atuação estatal no campo da atividade econômica em sentido estrito ("domínio econômico"), reafirmo a classificação que tenho me valido, que distingue três modalidades de intervenção: intervenção por absorção ou participação (a), intervenção por direção (b) e intervenção por indução (c).

No primeiro caso, o Estado intervém no domínio econômico, isto é, no campo da atividade econômica em sentido estrito. Desenvolve ação, então, como agente (sujeito) econômico.

Intervirá, então, por absorção ou participação.

Quando o faz por absorção, o Estado assume integralmente o controle dos meios de produção e/ou troca em determinado setor da atividade econômica em sentido estrito; atua em regime de monopólio.

Quando o faz por participação, o Estado assume o controle de parcela dos meios de produção e/ou troca em determinado setor da atividade econômica em sentido estrito; atua em regime de competição com empresas privadas que permanecem a exercitar suas atividades nesse mesmo setor.

No segundo e no terceiro casos, o Estado intervirá sobre o domínio econômico, isto é, sobre o campo da atividade econômica em sentido estrito. Desenvolve ação, então, como regulador dessa atividade.

Intervirá, no caso, por direção ou por indução.

Quando o faz por direção, o Estado exerce pressão sobre a economia, estabelecendo mecanismos e normas de comportamento compulsório para os sujeitos da atividade econômica em sentido estrito.

Quando o faz, por indução, o Estado manipula os instrumentos de intervenção em consonância e na conformidade das leis que regem o funcionamento dos mercados. (GRAU, 2018, p. $141 / 142$, grifos do autor)

Por esta classificação sugerida pelo Ministro da Suprema Corte Constitucional (Eros Grau) não é possível identificar qual ideologia políticoeconômica é adotada pelo Estado; pois, tomando como exemplo o Brasil, perpassasse por todas as modalidades intervencionistas, priorizando-as conforme as tendências político-governamentais dominantes.

Estabelecidas estas premissas quanto às formas abstratas de instrumentalização da intervenção no domínio, no capítulo subsequente passaremos à análise das normas in concreto destes instrumentos 
intervencionistas, particularmente quando instrumentalizados como infrações à ordem econômica.

\section{A INTERVENÇÃO DO ESTADO NO DOMÍNIO ECONÔMICO: INFRAÇÕES À ORDEM ECONÔMICA}

\subsection{INFRAÇÕES À ORDEM ECONÔMICA: INFRAÇÕES PRÓPRIAS}

Consoante bem elucida o Prof. Nelson Nazar, o ponto de partida de nossa perquirição deverá ser o texto constitucional:

O Direito Econômico relaciona-se com o Direito Constitucional, em que tem o seu fundamento de validade. É a norma fundamental, que dá base a tudo que se pratica no âmbito do país. Todas as demais normas têm incidências bem definidas, como mostra o professor Roque Carrazza em sua obra, Curso de Direito Constitucional Tributário (1991).

A Constituição Federal de 1988 estrutura uma rede de comandos, a qual é riquíssima. Portanto, a Constituição é norma de fundamento do Direito Econômico. (NAZAR, 2014, p. 49, grifos por conta do autor)

Como norma fundamental e fundamento de validade, a Constituição Federal de 1988 devota um título inteiro à ordem econômica e financeira, devotando ainda, um capítulo autônomo aos fundamentos do direito econômica (Capítulo I do Título VII).

Não obstante, seguindo as diretrizes dos enunciados constitucionais, o legislador infraconstitucional editou a Lei $n^{\circ} 12.529 / 2011$; a qual, por sua vez, dedicou um título inteiro à regulamentação das infrações à ordem econômica (Título V).

Pronto, delineado nosso postulado, inferimos que as infrações à ordem econômica se consubstanciam como os atos praticados por pessoas jurídicas de direito público ou privado que - independente de culpa (responsabilidade objetiva) - realizem as práticas legalmente proibidas (art. 36 da Lei $n^{\circ}$ 12.529/2011) e/ou infrinjam aqueles princípios constitucionais específicos (art. 170 da Constituição Federal).

Mais uma vez invocando a simplicidade que a presente investigação científica requer, passaremos à análise das modalidades de infração à ordem econômica reconhecidas pela doutrina nacional que, aqui, atribuir-lhes-emos o caráter de próprias. 
Sucintamente, a doutrina tradicional classifica as modalidades de infração no domínio econômico em dois grupos. O grupo das condutas coordenadas horizontais e o grupo das condutas unilaterais verticais.

Enquanto que as condutas coordenadas horizontais são condutas consumadas por dois ou mais sujeitos que visam, em conluio, influenciar determinado setor econômico para potencialização do lucro, ultrajando a ordem econômica (CASAGRANDE; PEREIRA NETO, 2016, p. 107); as condutas unilaterais verticais se traduzem como as condutas consumadas unilateralmente por determinado agente econômico que terminam influindo na ordem econômica, seja em seu benefício e/ou em seu malefício (OLIVEIRA; RODAS, 2013, p. 79).

Não obstante a complexidade que envolve a matéria, furtar-nos-emos da análise detida de cada classe; todavia, neste ponto vale repisar que a configuração de quaisquer das modalidades independe do elemento volitivo (responsabilidade objetiva), como bem elucidam os Profs. PEREIRA NETO e CASAGRANDE (2016, p. 99).

Ainda advogam os mencionados autores que, em razão da irrelevância do elemento volitivo, a mera prática de algumas destas infrações já configura ato ilícito, ao passo em que "excepcionalmente, determinadas condutas são consideradas sancionáveis mediante a comprovação de sua mera existência ou seja, nesses casos, elas são ilícitas em si mesmas, ou per se." (CASAGRANDE; PEREIRA NETO, 2016, p. 93, grifos dos autores)

Deste desiderato, arrematamos que as infrações à ordem econômica traduzem-se como as condutas que, praticadas em conjunto ou separadamente, descompassam a ordem econômica, independentemente da vontade do agente.

Neste ponto, vale a seguinte ressalva para fins do presente trabalho, conforme pormenorizaremos no tópico a seguir, atribuímos maior relevo ao valor consagrado no caput e no §único do art. 170 da CF e ratificado como regra no inc. I do art. 36 da Lei n ${ }^{\circ}$ 12.529/2011; qual seja, o princípio do livre exercício de qualquer atividade econômica.

\subsection{NORMAS TRIBUTÁRIAS COMO INSTRUMENTOS DE INTER VENÇÃO}

Decerto que o direito econômico é um ramo do direito autônomo como qualquer outro (tributário, penal, civil, 
administrativo, etc.) e, por esta razão, os instrumentos de intervenção no domínio econômico devem ser estudados sob sua ótica; apartada, a princípio, dos demais outros subsistemas.

São estas as lições do Prof. Nelson Nazar:

A intervenção do Estado no domínio econômico não é, por evidente, especificamente aquela sob a óptica do Direito Administrativo e do Direito Tributário, mas sim sob a óptica econômica, como já observado no Capítulo1.

A Constituição Federal de 1988, ao disciplinar a atividade econômica, abordou-a como sendo um gênero do qual fazem parte a atividade econômica em sentido estrito e os serviços públicos. (NAZAR, 2014, p. 91)

Entretanto, apegando-nos às lições inaugurais deste trabalho científico, manteremos firme o pressuposto de que o sistema de direito é uno e indivisível, ressaltando que sua ramificação só tem utilidade meramente dogmática. O que, por si só, já autoriza a análise dos instrumentos de intervenção na ordem econômica sob a ótica de outras "égides" do direito.

Não bastasse, ainda que segreguemos todos os ramos do direito como sistemas autônomas, é incontestável que todos eles - sem exceção - encontram fundamente de validade na Constituição Federal (1988); o que implica em, no mínimo, alguns momentos de interseção entre tais ramos.

A doutrina do próprio Dr. Nelson Nazar corrobora este raciocínio:

O Direito Tributário, o qual estuda os tributos fiscais e seus contornos, relaciona-se com o Direito Econômico a partir do momento em que a política tributária passa a intervir na economia.

A forma pela qual a política tributária intervém na política econômica é chamada de extrafiscalidade.

Por exemplo, quando há o intuito de estimular determinado setor da economia, o governo tem a possibilidade de reduzir a alíquota dos impostos incidentes, de forma a incentivar determinada atividade econômica. (NAZAR, 2014, p. 56)

Em sintonia com este predicado acerca das normas de direito tributário, Eros Grau registra que, não somente as prescrições que alteram o arquétipo da regra matriz de incidência tributária (tributo em abstrato) tem o condão de interferir na ordem econômica, como também as próprias normas que prescrevem benefícios fiscais:

Por outro lado, o Decreto n. 2.543A, de 5.1.1912 (resolução decretada pelo Congresso Nacional e sancionada pelo Presidente da República) (...) instituiu verdadeiro programa de 
desenvolvimento da cultura da borracha - ou de "defesa da borracha" (Alberto Venâncio Filho, ob. cit, pp. 145 e 464 e ss.) - que prevê: a isenção de impostos de importação; (...) inúmeras outras isenções tributárias e prêmios.(...) Tem-se, aí, talvez a experiência pioneira, entre nós, de instituição de um programa de medidas caracterizantes de intervenção por indução (v. item 64) na economia. (GRAU, 2018, p. 25)

Ora, pela perspectiva do Ministro da Supre Corte, fica cristalino que as normas tributárias são instrumentos do Estado, aptos a intervirem no domínio econômico, uma vez que se enquadram dentre as espécies da classificação sugerida pelo autor (v. item 1.3); mais precisamente, podem ser considerados instrumentos de intervenção por direção e/ou indução.

Sopesando estes pressupostos, parece-nos inegável que as normas que prescrevem condutas tributárias são instrumentos do Estado de intervenção na ordem econômica, razão pela qual merecem deter um pouco mais de nossa atenção.

\subsubsection{Normas tributárias como instrumentos de intervenção: Espécies Tributárias}

Furtando-nos da polêmica digladiada pela doutrina especializada acerca de quantas são as espécies tributárias, ao passo em que não é este o objeto do presente estudo, adotaremos a classificação chancelada pela Suprema Corte Constitucional.

Quando do julgamento do RE 146.733-9/SP(BRASIL, 2018a), albergado no voto relator do Min. Moreira Alves, o STF decidiu que são cinco as espécies tributárias (impostos, taxas, contribuição de melhorias, contribuições e empréstimo compulsório).

Destarte, imperioso trilhar que a doutrina que admite estas cinco espécies tributárias, ainda subdivide a espécie contribuição em contribuições sociais, contribuições de intervenção no domínio econômico - CIDE, contribuições de interesse das categorias profissionais ou econômicas e contribuições de iluminação pública. (PAULSEN, 2017, p. 51/52)

Consoante delineado acima, o legislador constitucional outorgou ao Estado (no caso, ao ente Federado União) a competência para instituir tributos que, em seu próprio nome, proclamam a finalidade de intervenção no domínio econômico (CIDE). 
Outrossim, precavendo os contribuintes das arbitrariedades do Estado, a Constituição Federal prescreveu diversas garantias, dentre as quais, uma das mais relevantes é o afamado princípio da anterioridade (ordinário/anual e nonagesimal).

Contudo, a assembleia constituinte entendeu que o cunho intervencionista na ordem econômica de alguns tributos - caráter extrafiscal é tão relevante que os excepcionou desta garantia constitucional, conforme prescrição do art. $150, \S 1^{\circ}$, da CF (II, IE, IOF, IPI, IR, impostos extraordinários e empréstimos compulsórios).

Ademais, ainda ponderando sua potencial propensão para intervir no domínio econômico, o legislador constitucional também excepcionou as contribuições sociais e as contribuições de intervenção no domínio econômico relativa às atividades de importação ou comercialização de petróleo e seus derivados, gás natural e seus derivados e álcool combustível do princípio da

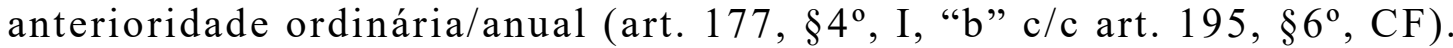

Neste mote, a Constituição Federal compreende que alguns tributos são revestidos de um caráter extrafiscal (potencial para inferir na ordem econômica) tão acentuado, que os excepcionou de garantias igualmente constitucionais (de ambas ou pelo menos de alguma das anterioridades).

De mais a mais, não são só as normas que delineiam o arquétipo da regra matriz de incidência tributária (tributo em abstrato) têm o condão de influenciar a ordem econômica, pois, revestem-se igualmente do caráter extrafiscal as normas que prescrevem benefícios fiscais.

Numa ou noutra espécie normativa, nas palavras do Min. Eros Grau (GRAU, 2018, p. 25), as regras regulamentadoras de condutas intersubjetivas que prescrevem normas tributárias se amoldam como instrumentos de intervenção no domínio econômico; contudo, na primeira hipótese (manipulação do arquétipo tributário), por direção, e na segunda hipótese (normas que prescrevem benefícios fiscais), por indução.

\subsection{INFRAÇÕES À ORDEM ECONÔMICA: INFRAÇÕES IMPRÓPRIAS (INSTRUMENTALIZADAS POR MEIO DE NORMAS TRIBUTÁRIAS)}

Consoante traçado nas linhas acima, especialmente quando se tratar de tributos constitucionalmente munidos do caráter extrafiscal, as normas que prescrevem regras tributárias têm o condão de interferir na ordem econômica. 
Há, porém, vezes em que o Estado se vale desta prerrogativa constitucional e utiliza as prescrições tributárias de forma coerente; outras vezes, no entanto, há flagrante abuso destas prerrogativas, o que deflagra as infrações à ordem econômica.

Notória semelhança com as condutas de infração à ordem econômica, notadamente com as práticas restritivas verticais. Senão vejamos a seguinte lição doutrinária:

Práticas restritivas verticais podem tanto ter efeitos benéficos como anticompetitivos. Dentre os efeitos benéficos que algumas práticas poderiam gerar estão a redução de custos de transação e a geração de economias de escala e escopo, por exemplo. (OLIVEIRA; RODAS, 2013, p. 80)

Ora, valendo-nos do exemplo trilhado pelo Prof. Nelson Nazar, tomemos como parâmetro o IPI:

Recentemente, em razão da grave crise internacional que vêm se alastrando desde meados do ano de 2008 por conta da recessão americana, o governo brasileiro, tendo em vista a marcante diminuição da venda de veículos novos e a fim de evitar o aumento das demissões pelas montadoras, resolveu reduzir o IPI dos automóveis fabricados no Brasil. (NAZAR, 2014, p. 56)

No exemplo supratranscrito, o autor traz uma clássica hipótese de manipulação do arquétipo tributário (redução da alíquota do IPI) como instrumento de intervenção no domínio econômico; neste caso, visando aquecer específico setor da economia até então desaquecido.

Por via transversa, vários outros exemplos demonstram que o Estado utiliza as prescrições tributárias de forma indevida e, ainda que de forma indireta (impropriamente), termina por desestimular determinados setores e por infringir a ordem econômica.

O caso recente mais alarmante, talvez seja o caso das contribuições sociais de PIS e COFINS, onde o Estado, por meio da adulteração do arquétipo tributário (base de cálculo), desestimulou - ainda que indiretamente - o setor industrial e o setor empresarial em geral; determinando que se enxertasse na base de cálculo daquelas contribuições sociais (PIS/COFINS) cifras indevidas, a exemplo do ICMS e do ISS. 
Para comprovar este desestímulo, basta noticiar o flagrante aquecimento na economia registrado por diversas matérias jornalísticas ${ }^{2} \operatorname{logo}$ após a decisão do Supremo Tribunal Federal que, ao julgar o RE $n^{\circ} 574.706^{3}$ (afetado ao regime de repercussão geral), decidiu por afastar o ICMS da base de cálculo do PIS e da COFINS.

Por seu turno, como já antecipamos alhures, as intervenções no domínio econômico não se lastreiam apenas por meio das normas tributárias que operam com o arquétipo da regra matriz de incidência tributária (tributo em abstrato), mas também se percebe pela instituição, revogação, majoração e minoração de benefícios fiscais.

Entendimento do Min. Eros Grau - instrumentos de intervenção por indução (GRAU, 2018, p. 25) - ao qual nos afiliamos, haja vista que os benefícios fiscais interferem sumamente na ordem econômica.

Como exemplo de manifesta infração à ordem econômica operacionalizada por meio benefício fiscal, trazemos o Decreto $\mathrm{n}^{\circ}$ 9.393/2018 que, contrariando a Suprema Corte Constitucional (RE 1.081.041) ${ }^{4}$, minorou quase que à revogação o benefício do chamado REINTEGRA (reduziu-o de $2 \%$ para $0,1 \%)$, desestimulando abruptamente e desacelerando o setor das indústrias que operam com exportações.

O efeito extrafiscal desta medida é tão assente que a União Federal (Estado) editou o Decreto $\mathrm{n}^{\circ}$ 9.393/2018 mesmo sabendo que seria expurgado pelo Poder Judiciário face a sua flagrante inconstitucionalidade; conquanto, insistiu nesta medida justificando que, até que o Poder Judiciário o censurasse, o efeito pretendido já teria sido alcançado (arrecadação); o que caracteriza insofismável infração à ordem econômica.

As questões aqui debatidas não repercutem apenas nas ordens financeiras e tributárias, mas refletem primordialmente na ordem econômica; ao passo em que aquece e desaquece setores da economia, gera empregos e ocasiona desempregos e, em última análise (ultima ratio), propicia ou dificulta o livre exercício da atividade econômica.

\footnotetext{
${ }^{2}$ CARRANÇA, Thais e TORRES, Fernando. Companhias Revertem R $\$ 2$ bi com base menor de PIS/Cofins. Valor Econômico, 10 maio 2018. Disponível em <https://www.valor.com.br/empresas/4963260/companhias-revertem-r-2-bi-com-basemenor-do-piscofins>. Acesso em: 08 set 2018. ${ }^{3}$ BRASIL, 2018b.

${ }^{4}$ BRASIL, $2018 \mathrm{c}$
} 


\section{INFRAÇÕES À ORDEM ECONÔMICA INTERNACIONAL}

\subsection{CONCEITO DE ORDEM ECONÔMICA INTERNACIONAL}

Albergando-nos nas premissas encravadas nos tópicos anteriores, escorreito sustentarmos que a ordem econômica é um microssistema que integra o macrossistema de determinado Estado; ou seja, volta-se à ordem interna de cada Estado soberano.

Posto de outra forma, a ordem econômica é o sistema próprio de cada Estado que se presta a influenciar sua ordem interna, especificamente, por meio da regulação das relações econômicas e sociais.

Contudo, este primado está incompleto e, por esta razão, não é absoluto.

O Min. Eros Grau (2018 p. 26/62) já proclamava em suas obras que não há como negar o surgimento de uma ordem econômica internacional; enquanto que o Prof. Nelson Nazar (2014, p. 61) atribuía o surgimento desta ordem ao processo de globalização.

Arremata Leonardo Vizeu Figueiredo elucidando que a ordem econômica internacional foi concebida com caráter cosmopolita e estruturada de modo a propiciar a cooperação entre as nações para, por meio de suas normas próprias, intensificar o comércio internacional. (FIGUEIREDO, 2016, p. $452 / 476)$

Aferrado nas lições doutrinárias destes ilustres cientistas, parece-nos inegável o surgimento de uma ordem econômica internacional, a qual se exacerba cada dia mais com a acentuação do processo de globalização.

Em contrapartida, com o encurtamento entre as fronteiras dos Estados soberanos, protagonizada primordialmente pela intensificação do processo de globalização, as oscilações ocorridas na ordem econômica interna de cada Estado repercutem na ordem econômica internacional.

D'outro lado, novamente com supedâneo nas lições do Prof. VIZEU FIGUEIREDO (2016, 453/501), conceituamos ordem econômica internacional como o conjunto de normas reconhecidas por dois ou mais Estados soberanos que prescrevem normas regulamentadoras das condutas internacionais; as quais, a pretexto de resguardar a ordem econômica mundial, primam pelos valores da sustentabilidade e racionalidade nas relações comerciais travadas entre países. 


\subsection{INFRAÇÕES À ORDEM ECONÔMICA INTERNACIONAL INSTRUMENTALIZADAS POR MEIO DE NORMAS TRIBUTÁRIAS}

Como visto no tópico anterior, a intensificação do processo de globalização vem estreitando os laços e diminuindo as fronteiras entre os Estados soberanos, outorgando relevância cada vez maior à manutenção da ordem econômica internacional.

Deste primado, quanto maior a proximidade entre os Estados soberanos, mais facilmente e rapidamente os distúrbios sucedidos na ordem econômica interna de um estado refletirá noutro. Sob outra perspectiva, com a acentuação do processo de globalização, as anomalias consumadas perante a ordem econômica interna de cada Estado soberano estão se fazendo repercutir cada vez mais rápido na ordem econômica internacional.

Ao revolvermos o exemplo do Benefício REINTEGRA, aferimos que esta medida governamental, além cominar na perda de mais de 105 mil postos de trabalho, ocasionou um prejuízo de mais de $\mathrm{R} \$ 13.000 .000 .000$ (treze bilhões de reais) à economia brasileira ${ }^{5}$; lesando também os consumidores internacionais que dependem dos produtos brasileiros.

E isto, sem sombra de dúvidas, reflete na ordem econômica internacional, posto que afeta todo o comércio externo, e ainda de forma mais abrupta os países que dependem primordialmente dos produtos nacionais.

O raciocínio despendido encontra alicerce na própria doutrina moderna que - representada pelo Prof. Leonardo Vizeu Figueiredo - prega que a ordem econômica interna influencia a ordem econômica internacional. (FIGUEIREDO, 2016, p. 498)

Pronto, posto este cenário e sopesadas estas premissas, sobeja incontestável que a ordem econômica interna e, reflexamente, a ordem econômica internacional, são afetadas por meio da instrumentalização de normas tributárias em desacordo com o ordenamento jurídico.

Medidas deste jaez auferem irrefutável caráter de barreiras tarifárias $^{6}$ às avessas, pois, não bastasse não serem editadas com o cunho protecionista

\footnotetext{
${ }^{5}$ GERBELLI, Luiz Guilherme. Redução do Reintegra por greve dos caminhoneiros deve trazer perdas de $\mathrm{R} \$ 13,3$ bilhões, diz associação. G1, 06 jun 2018. Disponível em $<$ https://g1.globo.com/economia/noticia/industria-deve-ir-a-justica-para-barrar-reducaodo-reintegra.ghtml>. Acesso em: 08 set 2018.

${ }^{6}$ Barreiras tarifárias são gravames impostos pelo Estado, com o fito de restringir ou inviabilizar a entrada de mercadorias estrangeiras (...). (FIGUEIREDO, 2016, p. 504)
} 
próprio às barreiras tarifárias, resultam no efeito prático exatamente reverso, ao passo em que restringem e/ou inviabilizam a saída dos produtos nacionais para o mercado externo.

Acrescentemos a isto o fato de que a própria doutrina especializada admite que a norma positiva (Lei $\left.n^{\circ} 12.529 / 2011\right)$ deixou uma lacuna quanto à definição de condutas unilaterais verticais (FORGIONI, 2010, p. 303); ao passo em que proclama que estas condutas tendem a refletir cada vez mais na ordem econômica internacional (OLIVEIRA; RODAS, 2013, p. 79).

Neste mote, parece-nos cristalino que as normas que prescrevem condutas tributárias, ao desrespeitarem os primados do ordenamento jurídico interno - considerando, aqui, também os tratados internacionais internalizados pelo Brasil -, consubstanciam-se como verdadeiros instrumentos de ferimento à ordem econômica interna e, por via de consequência, afiguram-se como instrumentos de ferimento à ordem jurídica internacional.

\section{CONSIDERAÇÕES FINAIS}

O novo sistema constitucional brasileiro, advindo com a proclamação da Constituição da República Federativa do Brasil de 1988, atribuiu demasiada relevância às normas que prescrevem regras voltadas ao direito econômico, reservando um título autônomo para tratar sobre a ordem econômica (Título VII da $\mathrm{CF})$.

Desta forma, não havendo dúvida de que o legislador constitucional imprimiu elevada relevância à ordem econômica, resta justificada a segregação doutrinária que sugere o estudo do direito econômico como matéria autônoma.

Por outro lado, bem fixamos a premissa de que todo o sistema de direito positivo é uno e indivisível, ao passo em que todas as normas que a ele (sistema) pertencem buscam fundamento de validade na Constituição Federal (ou, segundo Kelsen, na norma hipotética fundamental).

Advogando que o sistema é uno e indecomponível, restamos autorizados a sustentar que a norma produzida em qualquer "égide do direito" poderá refletir em "égide do direito" diversa.

Deste pressuposto, buscamos investigar as repercussões que as normas que prescrevem regras tributárias manifestam sobre a ordem econômica e, portanto, sobre o direito econômico. 
Por sua vez, assentamos que as anomalias acarretadas na ordem econômica interna refletem sobremaneira na ordem econômica externa, leia-se, na ordem econômica internacional.

Valendo-se do recente exemplo da anomalia provocada pela redução do Benefício do REINTEGRA, demonstramos que aquela medida governamental se afeiçoou como verdadeira "barreira tarifárias às avessas", posto que embaraçou a comercialização do produto nacional no mercado externo; ressoando não só na ordem econômica interna, como também na ordem econômica internacional.

Com isto, arrematamos que não pretendemos reduzir o direito econômico à uma subciência do direito derivada e subordinada ao direito tributário e, tampouco, ao direito financeiro (sua origem histórica); pretendemos, contudo, pautados na premissa de que o direito é uma ciência interdisciplinar una e indecomponível, demonstrar que as anomalias protagonizadas pelas normas que prescrevem regras tributárias repercutem na ordem econômica interna e externa e, consequentemente, no subsistema do direito econômico.

\section{REFERENCIAS}

BRASIL. Supremo Tribunal Federal (Tribunal Pleno). RE no 146733 /SP. Relator Min Moreira Alves. Brasília, 29 de junho de 1992. Disponível em: $<$ http://redir.stf.jus.br/paginadorpub/paginador.jsp?docTP=AC\&docID=21015 2>. Acesso em: 23 set 2018 a.

BRASIL. Supremo Tribunal Federal (Tribunal Pleno). RE no 574706/PR. Relator Min Cármen Lúcia. Brasília, 15 de março de 2017. Disponível em: $<$ http://redir.stf.jus.br/paginadorpub/paginador.jsp?docTP=TP\&docID=137095 50>. Acesso em: 23 set 2018b.

BRASIL. Supremo Tribunal Federal (Segunda Turma). RE n ${ }^{\circ}$ 1081041/SC. Relator Min Dias Toffoli. Brasília, 09 de abril de 2018. Disponível em: $<$ http://redir.stf.jus.br/paginadorpub/paginador.jsp?docTP=TP\&docID=147249 65>. Acesso em: 23 set $2018 \mathrm{c}$.

CARRANÇA, Thais e TORRES, Fernando. Companhias Revertem R\$2 bi com base menor de PIS/Cofins. Valor Econômico, 10 maio 2018. Disponível em <https://www.valor.com.br/empresas/4963260/companhias-revertem-r-2bi-com-base-menor-do-piscofins>. Acesso em: 08 set 2018.

CARVAlHo, Autora Tomazini de. Curso de Teoria Geral do Direito: O Constructivismo Lógico-Semântico. 3 ed. São Paulo: Noeses, 2013. 
CARVAlho, Paulo de Barros. Curso de Direito Tributário, 24 ed. São Paulo: Saraiva, 2012.

CASAGRANDE, Paulo Leonardo; PEREIRA NETO, Caio Mário da Silva. Direito Concorrencial. São Paulo: Saraiva, 2016.

FIGUEIREDO, Leonardo Vizeu. Lições de Direito Econômico. 9 ed. São Paulo: Forense, 2016.

FORGIONi, Paula A. Os Fundamentos do Antitruste. 4 ed. São Paulo: Revista dos Tribunais, 2010.

GERBELLI, Luiz Guilherme. Redução do Reintegra por greve dos caminhoneiros deve trazer perdas de $R \mathbf{R 1 3 , 3}$ bilhões, diz associação. G1, 06 jun 2018. Disponível em <https://g1.globo.com/economia/noticia/industria-deve-ir-a-justica-parabarrar-reducao-do-reintegra.ghtml >. Acesso em: 08 set 2018.

GRAU, Eros Roberto. A Ordem Econômica na Constituição de 1988. 19 ed. São Paulo: Malheiros Editores, 2018.

KELSEN, Hans. Teoria pura do direito. São Paulo: Martins Fontes, 1999.

NAZAR, Nelson. Direito Econômico. 3 ed. São Paulo: Edipro, 2014.

OLIVEIRA, Gesner; RODAS, João Grandino. Direito e Economia da Concorrência. 2 ed. São Paulo: Revista dos Tribunais, 2013.

PAUlsen, Leandro. Curso de Direito Tributário Completo. 8 ed. São Paulo: Saraiva, 2017.

VILANOVA, Lourival. As Estruturas Lógicas e o Sistema de Direito Positivo. 4 ed.São Paulo: Noeses, 2010.

VILELA, Danilo Vieira. Direito Econômico. São Paulo: Jus Podivm, 2016. 